Ks. Edward Lipiński, Łódi

\title{
NAMASZCZENIE W BETANII
}

Uczta i namaszczenie w Betanii miały miejsce na kilka dni przed śmiercią Chrystusa Pana. „Na sześć dni przed Pascha“" powiada św. Jan $(12,1)$ - przybył Jezus do Betanii. Chodzi tu najprawdopodobniej o urzędową Paschę świątynną ${ }^{1}$ ). Namaszczenie w Betanii odbyło się w sobotę wieczorem. Nie wynika wszakże $z$ tego, że Jezus przebył w szabat całą odległość dzielącą od Betanii miasteczko Jerycho ${ }^{2}$ ), a tym mniej Efrem położone prawie na skraju pustyni ${ }^{3}$ ).

Przy czytaniu Mateusza (26, 6-13) i Marka (14, 3-9) zdawać by się jednak mogło, że namaszczenie w Betanii nastąpiło dopiero w przeddzień wieczerzy paschalnej Chrystusa i Apostołów. Ale cały przebieg wydarzeń oraz ściślejsza chronologia czwartej ewangelii stanowczo nakazują trzymać się dokładnego dnia podanego przez św. Jana. Nie ulega też najmniejszej wątpliwości, iż mimo pewnych rozbieżności między relacją Jana a opowiadaniem dwu synoptyków jest tu mowa o jednym i tym samym wydarzeniu. Wyraźnie wskazują na to okoliczności. Uczta i namaszczenie mają miejsce w Betanii. Ktoś z grona Apostołów — Judasz według ściślejszej relacji Jana protestuje przeciw rozrzutności niewiasty, a Chrystus korzysta z tej okazji, by przepowiedzieć uczniom bliską już swoją śmierć. Poza tym Mateusz $(26,6)$ i Marek $(14,3)$ podają, że uczta odbyła się u Szymona. Jan nie wymienia imienia Szymona, ale daje do zrozumienia, że Łazarz był tylko jednym

1) Por. Jn 13, 1; 18, 28; 19, 14. 31. 42.

2) Por. Mt 20, 29; Mk 10, 46. Łk 19, 1.

3) Por. Jn 11, 54. 
z biesiadników (Jn 12, 2), nie zaś gospodarzem domu. Synoptycy nie podają imienia niewiasty, która dorogocennym olejkiem namaściła głowe Pana Jezusa (Mt 26, 7; Mk 14, 3), gdyż Maria była zupełnie nieznana ich czytelnikom: poprzednio bowiem nigdy o niej nie wspominali. Natomiast u Jana spotykamy ją już w rozdz. 11, 1-45, gdzie zaznaczone jest nawet w zdaniu nawiasowym $(11,2)$, że chodzi tu o tę samą Marię, która namaściła Chrystusa wonnym olejkiem i włosami swymi otarła Jego stopy. Maria jest więc osobą znaną czytelnikom. ewangelii Janowej i dlatego Jan wymienia ją po imieniu $(12,3)$.

Pozostaja jednak dwie trudności. Pierwszą z nich, to fakt, że Łukasz, który w swej ewangelii mówi o Marcie i Marii (10, 38-42), opuszcza opis namaszczenia w Betanii i podaje w całkiem innym kontekście podobną scenę namaszczenia stóp Chrystusa Pana przez jakąś jawnogrzesznicę (7, 35-50). Druga trudność wynika z rozbieżności zachodzącej między rela.s cjami Mateusza i Marka a opowiadaniem Jana. Rozbieżność ta dotyczy samego namaszczenia. Według Mateusza i Marka niewiasta wylała kosztowny olejek na głowę Chrystusa Pana (Mt 26, 7; Mk 14, 3), czyniąc to zgodnie ze zwyczajem podówczas powszechnie panującym na Bliskim Wschodzie, gdzie gościom skrapiano głowy wonnymi olejkami ${ }^{4}$ ). Natomiast według Jana $(12,3)$ Maria namaściła olejkiem stopy Jezusa i otarła je swoimi włosami naśladując bezimienną jawnogrzesznicẹ z ewangelii Łukaszowej ${ }^{5}$ ).

Z trudności tych wyłaniają się dwa zagadnienia. Pierwsze, literackie, dotyczące źródeł ewangelii i wzajemnych wpływów na kształtowanie się obecnego tekstu czterech èwangelii kanonicznych. Drugie, historyczne, polegające na możliwie najściślejszym ustaleniu rzeczywistego przebiegu wydarzeń.

$\mathrm{Z}$ punktu widzenia analizy literackiej jest rzeczą oczywistą, że w głównym źródle synoptyków, tj. bądź w greckim przekładzie Proto-Mateusza, bądź u Marka ${ }^{6}$ ), opis namaszczenia $\mathrm{w}$ Betanii był umieszczony między notatką o zebraniu ka-

$\left.{ }^{4}\right)$ Por. Ek 7, 46.

${ }^{5}$ ) Por. Ek 7, 38. 44. 46. 
płanów i starszych ludu a wzmianką o zdradzie Judasza. Wskazuje na to obecny układ Mt 26 i Mk 14 . Powodem podobnego umieszczenia tej perykopy były najprawdopodobniej słowa Pana Jezusa przepowiadającego Apostołom bliską już śmierć swoją, ciało Jego - twierdził - jest już namaszczone na pogrzeb $^{7}$ ). Chrystus daje to do zrozumienia, że specjalne okoliczności będą towarzyszyły Jego śmierci, choć nie mówi wyraźnie o jakimś końcu tragicznym ${ }^{8}$ ). Ten moment tragiczny podkreślają natomiast obydwie perykopy o postanowionym przez starszyznę żydowską uśmierceniu Chrystusa i o zdradzie Judasza. Opis namaszczenia w Betanii wprowadzony jest przez wzmiankę o decyzji powziętej przez kapłanów i starszych ludu oraz zakończony notatką o skontaktowaniu się Judasza z wrogami Chrystusa Pana. Istnieje więc pewne powiązanie logiczne między tymi trzema perykopami, które nawzajem się naświetlają. Tłumaczy nam to po części niechronologiczne umieszczenie przez źródło synoptyczne opisu uczty i ramaszczenia w Betanii.

Łukasz miał jednak wiele powodów do opuszczenia tej perykopy, którą niewątpliwie czytał w dokumencie źródłowym, na którym się w dużej mierze opierał. Epizod ten znalazłby się u niego w rozdziale 22 między w. 2 a 3 . Opuszczenie zaś tej sceny uczyniło opowiadanie Łukaszowe bardziej harmonijne. Równocześnie została przez to usunięta nieścisłość chronologiczna ${ }^{9}$ ). Prócz tego Łukasz zamierzał opowiedzieć pođobne wydarzenie, w którym występowała pewna jawnogrzesznica ${ }^{10}$ ).

6) Wyczerpującą bibliografię głównych prac, które ukazaly się na ten temat aż do roku 1953, można znaleźć u L. V a g a n a y, „Le Problème synoptique .Bibliothèque de théologie. Série III. Théologie biblique. Vol. 1), Paris-Tournai 1954, s. XIII-XXII. Syntetyczne ujęcie obecnego stanu zagadnienia oraz najnowszą bibliografię można znaleźć u J. Heuschen, „La formation des évangiles" w dziele zbiorowym p. t. „La formation des évangiles. Probleme synoptique et Formgeschichte" (Recherches bibliques II), Paris-Brugges 1957, s. 11-23.

7) Por. Mt 26, 12; Mk 14, 8 .

${ }^{8)}$ ) Por. F. Gils, „Jésus Prophète d'après les évangiles synoptiques“ (Orientalia et Biblica Lovaniensis, vol. II), Louvain 1957, s. 138.

9) Por. Jn 12, 1. 
Aby więc nie powtarzać podobnych do siebie scen, opuścił po prostu naszą perykope, z której jednak zapożyczył kilka konkretnych szczegółów celem ożywienia swego opowiadania o namaszczeniu stćp Chrystusa przez jawnogrzesznice. Takimi szczegółami, najprawdopodobniej zapożyczonymi z opisu namaszczenia w Betanii, które Łukasz czytał w swoim źródle, jest „naczynie alabastrowe“ 11) i imię faryzeusza, „Szymon“, które nie jest podare na początku perykopy Łukaszowej ${ }^{12}$ ).

Ale należy jeszcze wyjaśnić zyodność Łk 7, 38. 44. 46 z Jn 12, 3 przeciwko Mt 26, 7 i Mk 14, 3. Jawnogrzesznica u Łk 7, 38. 44. 46 i Maria u Jn 12, 3 namaszczają stopy Jezusa i ocierają je swoimi włosami. Natomiast niewiasta z Mt 26, 7 i Mk 14, 3, którą niewątpliwie jest Maria, namaszcza wedle zwyczaju głowę Pana Jezusa. Odnosi się wrażenie, że Jan oparł się częściowo na opisie Łukasza i zapożyczył od niego kilka szczegółów. Wskazują na to wymownie zestawienia słów wprost żywcem zaczerpnięte od Łukasza, którego ewangelia już istniała, gdy Jan zaczynał pisać swoją:

1) Jn 12, 3 : ..êleipsen ous podas tou Iêsou...

七k 7, 46: ...êleipsen tous podas mou...

七k 7, 38: ...tous podas autou kai êleifen...

2) Jn 11, 2 : ..ekmaksasa tous podas autou tais thriksin (tês kefalês) autês...

Jn 12, 3 : ...eksemaksen tais thriksin (tês kefalês) autês tous podas autou...

Łk 7, 44: ...mou tous podas kai tais tkriksin (tês kefalês) autês eksemaksen...

Łk 7, 38: ...tous podas autou kai tais thriksin (tês kefalês) autês eksemassen (eksemaksen)... ${ }^{13}$ )

Zestawienie tych zdań stanowi niewątpliwy dowód zależności literackiej Janowego opisu namaszczenia w Betanii od

10) Por. Ek 7, 36-50.

11) Por. Łk 7, $37 \mathrm{z}$ Mt 26, $7 \mathrm{i}$ Mk 14, 3.

13) Por. Łk 7, 36. 37. 39.

13) Por. aparat krytyczny. 
Łukaszowego opowiadania namaszczenia stóp Chrystusa przez jawnogrzesznicę. Dodać można, że św. Jan przy opracowaniu swej relacji skorzystał także $z$ równoległego opowiadania Marka i być może Mateusza. Wskazuje na to następujące zestawienie:

Jn 12, 3: ..labousa litran murou vardou pistikês polutimou...

Mk 14, 3: ..ekhousa alabastron murou vardon pistikês polutelous...

Mt 26, 7: ...ekhousa alabastron murou barutimou...

Dzięki tej porównawczej analizie literackiej usunęliśmy obie trudności. Historyczny przebieg wydarzeń możemy więc zrekonstruować w następujący sposób: Namaszczenie w Betanii miało miejsce $\mathrm{w}$ sobotę wieczorem. W czasie uczty Maria weszła do sali niosąc alabastrowe naczynie zawierajace funt, czyli około 35 deka, „prawdziwego olejku nardowego, bardzo. kosztownego". Rozbiła szyjkę flakonu i wylała jego zawartość na głowę Jezusa. Ta rzekoma rożzutność wywołała protest Judasza i odpowiedź Pana Jezusa, korzystającego z tej okazji, by raz jeszcze przepowiedzieć zbliżającą się godzinę swej śmierci. Dla niektórych krytyków, którzy zaprzeczają, jakoby Chrystus był kiedykolwiek przepowiedział swoją mękę, te słowa Zbawiciela są oczywiście czczym symbolizmem przypisanym namaszczeniu w Betanii przez późniejszą tradycję kościelną ${ }^{14}$ ). Opinia ta jest jednak pozbawiona jakiegokolwiek uzasadnienia egzegetycznego i dlatego odrzucają ją nawet liczni egzegeci niekatoliccy ${ }^{\mathbf{1 5}}$ ).

Bibliści, nieliczący się z analizą literacką, dodają do tych szczegółów, że Maria polała wonnym olejkiem również i stopy

$\left.{ }^{14}\right)$ Por. R. Bultma n n, „Die Geschichte der synoptischen Tradition“ (Forschungen zur Religion und Literatur des Alten und Neuen Testaments, XII), Göttingen $1931^{2}$, s. 283 - E. Lohmeyer, „Das Evangelium des Markus", Göttingen 1951, in h. 1.

$\left.{ }^{15}\right)$ Por. J. Jeremias, a. "Pais Theo" w G. Kittle1, ,Theologisches Wörterbuch zum Neuen Testament", t. V, Stuttgart 1954, s. 711 - V. T a y lor, ,The Gospel according to St. Marc"; London 1952, s. 533. 
Chrystusa Pana, które potem otarła swoimi włosami. Ze względu na wyniki analizy literackiej sądzimy, że te szczegóły nie należą do historycznego wydarzenia namaszczenia w Betanii, ale owszem do namaszczenia stóp Pana Jezusa przez bezimienną jawnogrzesznicę $w$ domu również bezimiennego faryzeusza.

Zachodzi tu jednak pytanie, czy podobna egzegeza i historyczna rekonstrukcja wydarzeń nie stoją w sprzeczności z katolicką nauką o natchnieniu i bezbłędności Pisma Swiętego. Innymi słowy, jeśli św. Jan podaje, że w czasie uczty w Betanii Maria namaściła stopy Pana Jezusa i następnie otarła je swoimi włosami, czy można utrzymywać, że nie miało to wówczas miejsca i że ten rys jest wyłącznie literacką ozdobą opowiadania zapożyczoną $\mathrm{z}$ opisu innego, podobnego wydarzenia przekazanego nam przez św. Eukasza?

Otóż na pytanie to odpowiemy twierdząco. Bóg bierze bowiem odpowiedzialność i zapewnia bezbłędność tej nauce, którą. zamierza nam przekazać autor natchniony. Zaszczytnym i mozolnym zadaniem egzegezy jest właśnie odkryć i jak najściślej określić zamiary autora biblijnego. Środkiem zaś prowadzącym do poznania intencji autora jest najpierw zrozumienie w ramach całego dzieła, celu, miejsca i wagi poszczególnych tematów oraz. szczegółów przezeń podanych. Następnie rozpoznanie po stylu, składni, użytym rodzaju literackim, nauki, jaką autor w pierwszym rzędzie zamierza wpoić w swego czytelnika. Jest bowiem. rzeczą niewątpliwą, że nie wszystkie twierdzenia i szczegóły mają dla autora tę samą wage, a zatem, że nie wszystkie gwarantują w ten sam sposób prawdomówność Bożą.

Aby więc jak najdokładniej uchwycić myśl i zamiary autora, należy ściśle określić znaczenie każdego wyrazu i każdego zdania, zbadać styl, przeniknąc strukturę poszczególnych perykop i całego utworu, wykryć paralelizmy literackie, zwroty zapożyczone, rysy i szczegóły skądinąd zaczerpnięte, rozpoznać rodzaj literacki i poprzez całą tę żmudną pracę przygotowawczą dojść do dokładnego zrozumienia nauki, jaką autor chciał przekazać swoim czytelnikom, oraz do uchwycenia celu, jaki 
mu przyświecał $\mathrm{w}$ trakcie pisania $\left.{ }^{16}\right)$. Słowem, trzeba w praktyce stosować zasady podane przez Ojca św. Piusa XII w encyklice „Divino afflante Spiritu“ ${ }^{17}$ ).

W naszym wypadku synoptycy pragną przede wszystkim uwypuklić proroctwo Chrystusa o bliskiej Jego śmierci. U Jana zaś cel ten schodzi na plan drugi; głównym natomiast jego zamiarem zdaje się być przygotowanie czytelnika do zdrady Judasza i podanie psychologicznego jej wytłumaczenia.

Drugą rzeczą, którą przy dogmatycznym ocenianiu naszego rozwiązania należy uwględnić, jest niezaprzeczalny fakt, że autorzy biblijni nie są reporterami, którzy by biernie przekazywali swym czytelnikom wydarzenia historyczne, których byli świadkami. Są oni autorami, którym przyświeca cel katechetyczny, kerygmatyczny lub parenetyczny ${ }^{18}$ ). Ich cel oraz związana z nim interpretacja pośredniczą między samymi wydarzeniami a przekazem, który do nas dotarł. Stąd pewne za-

16) Por. P. Benoît, a. „Inspiration“ w A. Robert-A. Tricot, „Initiation Biblique“, Paris-Tournai $1954^{3}$, s. 36-39, tenże, „Note complémentaire sur l'inspiration" w "Revue Biblique" 63 (1956) 418-420. Zasady te autor zastosował już przy egzegezie dwu relacji śmierci Judasza, przekazanych przez Mt 27, 3-10 i Dz Ap 1, 16-20. Zdaniem O. Benoît te dwie relacje są podaniami ludowymi, opartymi o podwójny fakt historyczny gwałtownej śmierci Judasza po dokonanej zbrodni i związku, istniejącego między wspomnianą śmiercią a pewnym polem dobrze znanym w Jerozolimie. Wychodząc $\mathrm{z}$ tych dwóch faktów historycznych podanie ludowe rozwinęło się w dwu częściowo rozbieżnych kierunkach, kładąc przy tym nacisk na spełnienie się proroctw i nie troszcząc się zbytnio o ścisłość podanych okoliczności. Według O. B e n o ît usiłowania majace na celu sharmonizowanie tych dwóch relacji nie odpowiadają wymogom krytyki literackiej. Należy więc ich zaniechać. Por. P. Benoît, a. „La mort de Judas" w "Synoptische Studien. Alfred Wikenhauser zum siebzigsten Geburtstag dargebracht...", München 1954, s. $1-19$.

17) Por. AAS. 35 (1943) 314-315; Denzinger, ,Enchiridion Symbolorum“, Barcelona $1950^{28}$, $\mathrm{nr} 2294$.

${ }^{18)}$ Por. A. Descamps, a. „Esquisse du christianisme primitif“ W „Revue diocésaine de Tournai““ 1 (1946) 493 - tenże, „Les Justes et la Justice dans les évangiles et le christianisme primitif, hormis la doctrine proprement paulinienne" (Universitas Catholica Lovaniensis, Diss. theol., ser. II, vol. 43), Louvain-Gembloux 1950, s. 165, uw. 1 
barwienie wydarzeń właściwe każdemu ewangeliście. Ewangelie nie są więc fotografią, ale portretem. Nie są one jakąś kroniką rejestrującą szereg gołych faktów, ale owocem myśli zastanawiającej się nad osobą i dziełem Chrystusa i wnikającej w przeróżne aspekty tak bogatej treściowo nauki Chrystusowej ${ }^{19}$ ).

Z książki Dom J. D u p o n t pt. „Les Béatitudes“ (BrugesLouvain 1954) można się przekonać, jak owocne jest dla egzegezy i dla teologii biblijnej uwzględnianie tej różnicy między pierwotnym i historycznym sensem słów i wydarzeń biblijnych a interpretacją autora natchnionego, pogłębiającego i rozwijającego pod wpływem Ducha Świętego nauki w nich zawarte. Warto by przytoczyć tu na poparcie tych wywodów słowa Chrystusa Pana: „Miałbym wam jeszcze wiele do powiedzenia, lecz nie jesteście w stanie obecnie znieść tego. Ale gdy on przyjdzie, Duch prawdy, nauczy was wszelkiej prawdy" ${ }^{20}$ ).

Oprócz trudności wyżej wymienionych wymaga wyjaśnienia jeszcze jedno zdanie Janowej perykopy o uczcie w Betanii. Jest to wiersz 7. Pewna trudność nastręcza tu zrozumienie spójnika 'ina. Gdyby wprowadzał on w tym wierszu podrzędne zdanie celowe, zdanie brzmiałoby w tłumaczeniu: „Daj jej pokój, aby zachowała olejek na dzień mego pogrzebu“. Podobny zaś sens jest niemożliwy, ponieważ Maria wylała już olejek. Zresztą u Mateusza i u Marka słowa Pana Jezusa stanowią wyraźną interpretację tego namaszczenia, jakoby ono było uprzedzeniem przygotowania ciała Zbawiciela na bliski już pogrzeb. Nie chodzi tu więc o zachowanie olejku celem przyszłego jego użycia przy pogrzebie Chrystusa, ale o symboliczną interpretację namaszczenia już dokonanego.

Gdyby było rzeczą udowodnioną, że spójnik 'ina ma w Nowym Testamencie niejednokrotnie znaczenie przyczynowe, trudność byłaby rozwiązana. Ów wiersz brzmiałby bowiem w przekładzie: ,Daj jej pokój, gdyż zachowała olejek na dzień mego pogrzebu". Pan Jezus dałby przez to do zrozumienia, że

19) Por. P. B e n ô̂t w „Revue Biblique“ 63 (1956) 421—422 i 439—440.

${ }^{20}$ ) Por. Jn 16, 12-13. 
śmierć Jego jest już tak bliska, iż to namaszczenie może uchodzić za namaszczenie Jego martwego ciała na pogrzeb. Ale zdania filologów są podzielone ${ }^{21}$ ). Sądzimy wszakże, że istnieją poważne racje przemawiające za uwzględnieniem w pewnych określonych wypadkach przyczynowego znaczenia spójnika 'ina w pismach Nowego Testamentu. Już w drugim wieku po Chr. Apoloniusz Dyskolos ${ }^{22}$ ) wyraźnie zaznacza, że 'ina jako spójnik posiada podwójne znaczenie, jedno przyczynowe, drugie celowe ${ }^{23}$ ). Warto zaś zaznaczyć, że jego prace gramatyczne opierały się na dawniejszych jeszcze opracowaniach gramatyków aleksandryjskich ${ }^{24}$ ).

Filolodzy, którzy utrzymują istnienie przyczynowego znaczenia spójnika 'ina w Nowym Testamencie ${ }^{25}$ ), przytaczaja. wśród innych przykładów Jn 8, 56: „Ojciec wasz Abraham uradował się, iz ('ina) ujrzał dzień mój". Natomiast większość egzegetów sądzi, że 'ina zastępuje tu bezokolicznik ${ }^{26}$ ). Jeśli nawet. przyjmiemy to ostatnie wyjaśnienie, to sens podrzędnego zdania wprowadzonego przez 'ina pozostaje zasadniczo ten sam. Jest w nim wyrażona przyczyna radości Abrahama. Podobną. składnię i podobny sens mamy u Jn 12, 7. Spójnik 'ina wprowadza tu zdanie podrzędne, które określa przyczynę, dla której Judasz ma zaniechać swych utyskiwań z powodu rzekomej

$\left.{ }^{21}\right)$ Por. M. Z e rwick, Graecitas Biblica, Romae $1955^{3}$, nr 291-293.

$\left.{ }^{22}\right)$ Apolloniusz Dyskolos z Aleksandrii opracował wszystkie cześci gramatyki. Ponieważ był pierwszym i jedynym gramatykiem starożytnym, który zestawił całą składnię, stał się dla autorów późniejszych jedyną powagą na tym polu. Por. T. Sin k o, „Literatura grecka“, t. III, cz. 1, Kraków 1951, str. 289-291.

${ }^{23}$ ) Por. wydanie dzieł Apolloniusza: R. Schneider w ,Corpus grammaticorum graecorum"; Pars II, 1, 1; Lipsk 1878, str. 243.

${ }^{24}$ ) Por. T. S in k o, dz. cyt., str. 289.

$\left.{ }^{25}\right)$ Por. H. Pernot, „Etudes sur la langue des Evangiles“, Paris 1927, str. 91-92 - Fr. La Cava, „Ut videntes non videant“, Torino $1934-$ tenże, „Ne quando convertantur“, Torino 1935 - tenże, art. „Una lettera di Sant'Isidoro Pelusiota“ w ,Divus Thomas“ (Piacenza), 39 (1936) 529-533 - E. L o h m e ye r, „Das Evangelium des IMarkus“, Göttingen 1951, in Mk IV, 12.

26) Por. F. Blass - A. Debrunner, ,Grammatik des neutestamentlichen Griechisch", Göttingen $1948^{8}$, nr 392, 1 a. 
rozrzutności Marii. Znaczenie wiersza jest więc następujące: „Nie miej jej za złe, iż zachowała olejek na dzień mego pogrzebu“. Tłumaczeniu temu nie sprzeciwia się forma czasownika têrê̂, gdyż poza trybem oznajmiającym tryby osobowe aorystu nie oznaczają czasu ${ }^{27}$ ).

Tak więc odpowiedź Chrystusa w relacji św. Jana treściowo pokrywa się z Jego słowami przytoczonymi przez synoptyków. A zatem usunęliśmy wszystkie trudności i pozorne sprzeczności obydwu relacji uczty i namaszczenia w Betanii.

Louvain KS. EDWARD LIPINSSKI

$\left.{ }^{27}\right)$ Por. M. Z e rw i ck, dz. cyt., nr 180 - C. Van de Vorst, „Grammaire Grecque“, Liège $1946^{12}$, sr 275. 